\title{
Academic Intellectual Capital Scale: A Validity and Reliability Study
}

\author{
Ugur Ozalp ${ }^{(1, *}$, Munevver Cetin ${ }^{2}$
}

${ }^{1}$ Marmara University, Faculty of Education, Department of Educational Sciences, İstanbul / Turkiye

\author{
ARTICLE HISTORY \\ Received: June 01, 2021 \\ Revised: Dec. 24, 2021 \\ Accepted: Jan. 04, 2022 \\ Keywords: \\ Academic intellectual \\ capital, \\ Intellectual capital, \\ Higher education.
}

\begin{abstract}
The aim of this study was to develop a scale instrument for measuring academic intellectual capital in the Turkish higher education context depending on student perceptions. The sample consisted of students of higher education institutions in the 2020-2021 academic year. Data were gathered in two stages. Exploratory Factor Analysis (EFA) was conducted in the first stage and Confirmatory Factor Analysis (CFA) was conducted in the second stage. The EFA sample consisted of 538 students studying in 96 higher education institutions while the CFA sample consisted of 492 students studying in 112 higher education institutions. Principal Axis Factoring (PAF) extraction and Promax rotation methods were used in EFA. Results of EFA showed that the scale had a three-factor structure with 20 items. The three-factor structure was confirmed with CFA. Cronbach's alpha, stratified alpha, Composite Reliability and McDonald's omega were calculated in order to determine the reliability of the scores obtained from the scale. Item discrimination was verified by calculating item-total correlation and item-remainder correlation. Also, t-test was carried out between upper and lower $27 \%$ to check item discrimination. Analyses were conducted making use of R (ver. 4.1.2) and RStudio (ver. 2021.09.1 build 372). Overall, results showed that the structure of Academic Intellectual Capital Scale was valid. The measurement tool was concluded to have three factors and 20 items, all in affirmative form.
\end{abstract}

\section{INTRODUCTION}

The ever-changing nature of competition makes it obligatory for organizations to step ahead of their competitors in the context of meeting the expectations of the stakeholders. Representing the future-facing side of the societies and serving as a bridge between theory and practice, higher education institutions are also affected by this competitive environment. Academic intellectual capital of higher education institutions is among the variables that are effective in making difference in the competition.

Together with technological, economic, social and political innovations, intellectual capital is among the concepts that the fourth industrial revolution has brought along, seeking the ways to overcome encountered problems in management, planning, practice, strategy, analysis,

*CONTACT: Ugur OZALP $\bigotimes$ ozalp.ugur@gmail.com Department of Educational Sciences, İstanbul / Turkiye
Marmara University, Faculty of Education, 
cooperation, human resources, change and leadership (el Hamdi et al., 2019; Mohamed, 2018; Schneider, 2018; Suciu \& Năsulea, 2019). Like many other concepts in social sciences, there is no consensus on the definition of intellectual capital (de Castro et al., 2010). Some scholars focused on its being knowledge-based (Bontis et al., 2002; Cabrita \& Bontis, 2008; Chang et al., 2008; Dzinkowski, 2000; Holland \& Holland, 2010; Nahapiet \& Ghoshal, 1998), some others focused on its providing competitive advantage (de Castro et al., 2010; Delgado-Verde \& Cruz-González, 2010; Hsu \& Fang, 2009) and some others focused on its having potential to turn into inter-organizational value (Martínez-Torres, 2006; Sohrabi et al., 2010).

Intellectual capital is a combination of all the intangible assets and skills of the members of the organization. Managing this combination serves as a useful tool in the value creation process for the administrators (Brătianu \& Pînzaru, 2015). Besides, it affects the decision-making processes of stakeholders by presenting valid and transparent data (Ramírez \& Gordillo, 2013; Todericiu \& Stanit, 2016). It also contributes to strengthening the long-term vision of the organization, increases the satisfaction that the stakeholders experienced as a result of sense of confidence towards the organization, and helps positive corporate image and corporate reputation building (Ramirez et al., 2016).

Intellectual capital represents the total knowledge of the members of an organization. In other words, it is the collective ability of members which involves perception of knowledge and learning. Organizations are able to gain competitive advantage by making decisions involving production thanks to their intellectual capital which represents intangible assets they possess. Intellectual capital stems from interactions of organizations with their environments and its value increases as long as it is used. Apart from constituting a competitive advantage providing factor, intellectual capital is also an essential tool for creating internal value (Kelly, 2004b; Ren, 2009; Roos et al., 1997; Semenov, 2016).

As it depends mostly on knowledge, it is impossible to completely eradicate intellectual capital. In addition, being knowledge-dependent prevents it from value loss and its value constantly increases. In addition to its being at no cost for organizations, it also constitutes both input and output of the value creation process in the organization. Because it is in the minds of the members and placed in the processes of the organization, intellectual capital is also an inimitable source (Dean \& Kretschmer, 2007; Sohrabi et al., 2010).

Although there are various classifications regarding the dimensions of intellectual capital, it was observed that a considerable number of studies classified it as human capital, structural capital and relational capital (Bontis, 1998; Carson et al., 2004; Chan, 2009; de Castro et al., 2010; Delgado-Verde \& Cruz-González, 2010; Huang et al., 2007; O’Donnell \& O’Regan, 2000; Pedrini, 2007; Saint-Ogne, 1996).

Human capital represents know-how, experiences and skills of the members of the organizations (de Castro et al., 2010). It is used for expressing the importance of the abilities and problem-solving skills of the individuals for the organization (Suciu \& Năsulea, 2019). It is the collective knowledge and experience that provides sustainable competitive advantage to the organization (Kelly, 2004a). Fitz-enz (2019) puts forward that it is the combination of the elements that an individual brings to the organization such as intellect, commitment, imagination and creativity. It refers to the knowledge, skills and abilities in the minds of the members of the organization that they use for achieving organizational goals. As it does not belong to the organization, losing members is a threat for the organization in terms of human capital. One of the most important skills for the organizations is to preserve the human capital they have and thus, become the center of attraction for the human capital their competitors possess (Bontis, 1998; Bontis et al., 2000; Chen et al., 2004; Demir, 2018; Görmüş, 2009; Kaya \& Kesen, 2014; Kutlu, 2009). 
Structural capital refers to the processes, procedures, strategies and policies that shape and develop the organization. Structural capital includes the organizational structure and technological infrastructure of the organization (de Castro et al., 2010; Suciu \& Năsulea, 2019). Members of the organization provide intellectual input that shapes structural capital. This aspect makes it specific to the organization (Sohrabi et al., 2010). Structural capital is implicit knowledge acquired through language and narratives embedded in the social interactions between members of the organization and includes organizational capabilities developed to meet market requirements. In this context, it can be stated that all management tools, infrastructures, R\&D studies, patents or trademarks used for increasing the efficiency and productivity of the organization are part of the structural capital. Organizations with strong structural capital have a supportive culture that allows organization members to make innovative attempts, fail and learn from the experience of failure (Bontis, 1998, 2002; Bontis et al., 2000; Dzinkowski, 2000; Mura \& Longo, 2013).

Relational capital expresses the sum of assets of the organization regarding its relations with its environment. Relational capital refers to the relations of an organization with the stakeholders, beneficiaries of its products or services, its external environment, suppliers, government agencies, the society and its competitors (Bontis, 2002; Bozbura \& Toraman, 2004; de Castro et al., 2010; Fitz-enz, 2019; Sohrabi et al., 2010; Suciu \& Năsulea, 2019). It is the basic indicator of turning intellectual capital into production and added value. Without relational capital, it is not possible to create marketing value or obtain corporate performance. Relational capital blooms on human capital and structural capital. As it depends on customer loyalty and relations with suppliers which are out of the boundaries of influence of the organization, it is the most difficult dimension of intellectual capital to build. Just like human capital, it is not owned by the organization. It is important to turn relational capital into a part of structural capital (Baş et al., 2014; Bontis, 1998; Bontis et al., 2000; Chen et al., 2004; Dzinkowski, 2000).

Intellectual capital is an important power source for an organization in competition. Expressing the innovative power and innovative potential of organizations, intellectual capital is also important for higher education institutions that adopted long-term sustainable development as principle. Measurement of intellectual capital and sharing the results with the stakeholders provide higher education institutions with the opportunity to strengthen the perception regarding their reputation (Kelly, 2004b; Matos et al., 2019; Suciu \& Năsulea, 2019).

In the era of a knowledge-based economy, increasing intellectual capital potential depends on education. In addition to providing other benefits, education has an indisputably important role in the future of countries with the economic incomes it brings (Chatterji \& Kiran, 2017; Jakubowska \& Rosa, 2014). Intellectual capital affects the efficiency of instruction and research which are among the duties of higher education institutions and constitutes input for education simultaneously (Lu, 2012; Sánchez et al., 2009). Higher education institutions produce and market certificates presenting evidence for the degree earned as product, and instruction, learning and socialization opportunities as services. Perception regarding the products and services directly affects the value attributed to them (Brenca \& Gravite, 2013).

In an academic context, intellectual capital refers to intangible assets such as innovation capacity, patents owned, skills of the members or social level of acceptance (Ramírez \& Gordillo, 2014). Kelly (2004b) puts forward that academic intellectual capital is the knowledge of the faculty members and its reflection on turning the knowledge into values. In this respect, the added value that academic intellectual capital provides both for the society and the higher education institutions which are expected to contribute to economic growth, to lead up social developments and to promote entrepreneurship should be investigated (Brătianu \& Pînzaru, 2015; Mariani et al., 2018). Academic intellectual capital comprises the input of the knowledge creation process in higher education institutions. It refers to all intangible sources that provide 
basis for knowledge and have the potential to provide a competitive advantage. Consequently, in an academic context, intellectual capital indicates elements beyond accounting (Leitner, 2004).

Academic intellectual capital is directly related to the qualifications of the members of the organization and it refers to the intellectual value of human potential in education, research and socialization processes. Elements such as qualifications of faculty staff, use of physical and technological resources for improving instruction and research, student or faculty mobility, and ownership of intellectual properties are within the scope of academic intellectual capital (Brenca \& Garleja, 2013; Silva \& Ferreira, 2019). In addition to these, academic intellectual capital has a positive influence on the life quality of societies by affecting the sustainable development of the countries (Pedro et al., 2020).

In educational contexts in which both the input and the output are people and knowledge, it is of great importance to effectively and efficiently manage intellectual capital - the intangible assets (Basile, 2009; Karakuş, 2008; Kelly, 2004b; Ramírez Córcoles \& Tejada Ponce, 2013). Measurement of academic intellectual capital is expected to lead to managerial, cultural and organizational changes and it is important as it will set the future route of the higher education institution (Kelly, 2004b; Todericiu \& Şerban, 2015). In addition to its providing an indicator for the quality of instruction, measuring academic intellectual capital is also expected to provide insight about the competitive advantage of the institution in an international context (Lu, 2012).

A number of scales were developed to measure intellectual capital. However, a significant number of them focus on business organizations and most of them depend on the opinions of senior executives of the firms. For example, Bontis (1998) developed a tool for measuring the intellectual capital of the firms and carried out the study with MBA students who represented the organizations they worked in. Another example is a study by Chen et al. (2004) which was carried out by participation of entrepreneurs, general managers or the top executives of hightech enterprises. Youndt and Snell (2004) also developed an intellectual capital scale targeting top-level executives of firms. Another scale developed by Subramaniam and Youndt (2005) involved the executives and vice presidents of human resources of enterprises. Huang et al. (2010) developed a scale with the participation of managers of companies. Another scale is of Han and Li (2015) that was developed with the participation of middle or senior managers of firms. Another intellectual capital scale by Asiaei and Jusoh (2017) used chief financial executives as the data source. Another example is by Urban and Joubert (2017) in which their data source was CEOs or owners of enterprises. Apart from making use of scales developed for business environment in the academic context, it was observed that scales for measuring academic intellectual capital were not common in the literature. For example, de Frutos-Belizón et al. (2019) developed an academic intellectual capital scale for measuring the perceptions of academics and researchers.

In the above-mentioned scales, it was observed that decision-makers are used as a data source in general. Cabrita and Vaz (2005) propose that evaluation of intellectual capital requires awareness in terms of organizational strategy and these strategically aware individuals are mainly chief executive officers, directors or top-level administrators. However, in this study, student perceptions regarding intellectual capital are in focus. We believe that, for educational institutions, students constitute both the input and the output of the process. From this point of view, it is thought that the scale developed in this study will contribute to the literature in terms of reflecting perceptions of different stakeholders of educational processes in a higher education context. 


\section{METHOD}

In this section, information regarding the sample is presented and steps of scale development are explained in detail.

\subsection{Sample}

The snowball sampling method which allows data collection in case of population listing is not possible or it is impossible to compile the entire list was used in this study (Fink, 2010). Snowballing started with 40 students studying at various higher education institutions in the 2020-2021 academic year. A total of 1117 students from 112 institutions were reached for data collection.

OECD/Eurostat (2018) puts forward that it is appropriate to make use of online data collection techniques in academic studies. In addition to its being a low-cost way in terms of both time and money, online data collection also enables researchers to gather data in electronic format. Thus, it becomes easier to analyze the data (Harris et al., 2007; Tajvidi \& Karami, 2015). Online data collection also provides the researcher with the comfort of suppressing the missing data by not allowing the participant to continue without answering certain questions (OECD/Eurostat, 2018). However, on the other hand, online data gathering also holds the probability of low participation level or poor data (Sultan \& Wong, 2019). Data in this study were gathered online by making use of Google Forms. For securing the data quality, a control item requesting participants to choose a certain answer (For this item, please choose 'partially true' option) was also included in the form.

Data were collected in two stages: 574 students participated in the first stage in which EFA was conducted and 543 students participated in the second stage in which CFA was conducted. However, 36 participants from EFA and 51 participants from CFA were excluded from the analyses as they were confirmed to give the same answer for all the items and/or did not follow the control item. In the first stage, data were gathered from 538 students studying in 96 universities included in the study. Following EFA, in the second stage, data were collected from 492 students in 112 universities who didn't get involved in the first stage of the study. Data regarding the participants are presented in Table 1.

Table 1. Participants.

\begin{tabular}{lcccc}
\hline & \multicolumn{2}{c}{$1^{\text {st }}$ Stage } & \multicolumn{2}{c}{$2^{\text {nd }}$ Stage } \\
\hline Female & $\mathrm{N}$ & $\%$ & $\mathrm{~N}$ & $\%$ \\
Male & 352 & 65.43 & 307 & 62.40 \\
\hline Associate & 186 & 34.57 & 185 & 37.60 \\
Bachelor's & 52 & 9.67 & 60 & 12.19 \\
Master's & 313 & 58.18 & 208 & 42.28 \\
Doctoral & 138 & 25.65 & 162 & 32.93 \\
\hline State University & 35 & 6.50 & 62 & 12.60 \\
Foundation University & 471 & 87.55 & 413 & 83.94 \\
\hline Research University & 67 & 12.45 & 79 & 16.06 \\
Candidate Research University & 45 & 8.36 & 74 & 15.04 \\
Other State University & 38 & 7.07 & 25 & 5.08 \\
Foundation University & 388 & 72.12 & 314 & 63.82 \\
\hline Total & 67 & 12.45 & 79 & 16.06 \\
\hline
\end{tabular}


Table 1 shows that there were 352 female and 186 male participants in the $1^{\text {st }}$ stage while there were 307 female and 185 male participants in the $2^{\text {nd }}$ stage. Besides, 52 associate degree students, 313 bachelor's degree students, 138 master's degree students and 35 doctoral students participated in the $1^{\text {st }}$ stage; 60 associate degree students, 208 bachelor's degree students, 162 master's degree students and 62 doctoral students participated in the $2^{\text {nd }}$ stage. Out of 471 state university students who participated in the $1^{\text {st }}$ stage, 45 were studying at research universities, 38 were studying at candidate research universities, and 388 were studying at other state universities. Out of 413 state university students who participated in the $2^{\text {nd }}$ stage, 74 were studying at research universities, 25 were studying at candidate research universities and 314 were studying at other state universities.

DeVellis (2017) emphasizes that sample size in EFA is a controversial issue. Similarly, Johnson and Morgan (2016) state that there is no universal rule of thumb for sample size in EFA. However, they put forward that the more the number of participants the better EFA will result. Field (2018) claims that it is essential to have more than 300 participants in order for the results of EFA to be reliable. On the other hand, Irwing and Hughes (2018) assert that the number of participants in EFA is expected to exceed 500 if it is aimed to generalize the results. Similarly, Worthington and Whittaker (2006) put forward that there need to be over 300 participants for CFA. In this perspective, it is possible to state that 538 participants for EFA and 492 participants for CFA are sufficient.

\subsection{Development of the Scale}

In scale development, primarily, answers for the following questions are sought (Lane et al., 2016): What is the measured structure? Who will be the participants? How will the results be used? What will the scale format be? Büyüköztürk et al. (2020) propose that a scale can be developed in seven steps: (1) defining the purpose of the scale, (2) determining the feature to be measured, (3) preparing the draft item pool, (4) technical supervising and inspecting in terms of language, (5) gathering expert opinions, (6) collecting data, (7) evaluating psychometric aspects of the scale. In this study, the abovementioned steps were followed for scale development.

\subsubsection{Purpose of the scale}

At this stage, the target group of the scale, how the results will be interpreted and how the results will be used is decided (American Educational Research Association, 2014; Büyüköztürk et al., 2020). In this context, the target group of the Academic Intellectual Capital Scale was decided to be students who are studying in higher education institutions. Also, it was decided that the results of the scale to be used for evaluating the level of perceived academic intellectual capital level of the higher education institutions.

\subsubsection{Feature to be measured}

According to Johnson and Morgan (2016), researchers develop scales to measure the knowledge level, behavior or perceptions of the participants. At this phase, it is decided whether the scale should focus on apprehension, attitude, self-efficacy or academic success (Büyüköztürk et al., 2020). In this study, it was decided to measure the level of perception of the participants with the scale.

\subsubsection{Draft item pool}

Different techniques such as literature review, interview or consulting expert opinions for item development are widely used. It is important to consider that the number of items in the pool should both be manageable for the researcher and not be time-consuming for the participants (Büyüköztürk et al., 2020; DeVellis, 2017; Johnson \& Morgan, 2016). Carpenter (2018) emphasizes that reviewing literature holds importance in determining the factor structure of a 
phenomenon. At this stage, it was decided to review the literature for preparing the draft item pool. Following the literature review, it was inferred that academic intellectual capital might have three underlying factors: academic human capital, academic structural capital, academic relational capital. It was also decided that the scale would be in five-point Likert format. Finally, a draft item pool consisting of 90 items was prepared and the options for the items were decided: (1) not true at all, (2) partially true, (3) fifty-fifty, (4) true to a great extent, (5) completely true.

\subsubsection{Technical supervision and inspection in terms of language}

At this stage, together with language clarity, the convenience of the items for the structure intended to be measured are inspected (Büyüköztürk et al., 2020; Lane et al., 2016). For this reason, draft item pool was sent to a panel of 4 language experts who hold a bachelor's degree in the Turkish Language. Depending on the panel's feedback on punctuation and grammar, items in the draft pool were revised.

\subsubsection{Opinions of panel of experts}

Content validity refers to the level of the items' representing the structure intended to be measured (Markus \& Smith, 2010; Martinez, 2017). Evaluation of content validity allows researchers to eliminate the items which do not serve the purpose of the scale (Litwin, 2002). Content validity also serves as an indicator of construct validity (Markus \& Lin, 2010).

Wilson et al. (2012) state that the most widely used technique for evaluating the content validity in most of the fields such as education, health, organizational development, marketing, psychology is the Content Validity Ratio (CVR) proposed by Lawshe (1975). CVR, calculated depending on the opinions of a panel of experts, provides a quantitative basis for evaluating the items before deciding on the inclusion of them in the scale (Gilbert \& Prion, 2016). As this approach is built upon gathering the opinions of field experts, it holds great importance to decide on the members of the panel of experts for ensuring the content validity (American Educational Research Association, 2014).

In order to determine content validity, draft item pool was sent to a panel of experts. Experts were decided depending on the criterion sampling method. Criteria for the experts were stated as follows: having a Ph.D. degree in the educational administration field, having research on higher education management and working in a higher education institution. 1 scholar holding professor title, 6 scholars holding associate professor title and 6 scholars holding assistant professor title, totally 13 academics from 9 higher education institutions were reached for expert opinion.

Depending on expert opinions, CVR for each item was calculated using Lawshe's formula (1975) and evaluated using Content Validity Criterion (CVC) proposed by Ayre and Scally (2014). Ayre and Scally (2014) inform that CVC for a panel of 13 experts is .538. Following the opinions of experts, it was determined that 31 items out of 90 were found to be suitable for the scale. 31 items in the pool are presented in Table 2.

Please note that items written in English in Table 2 are provided only to give insight about items in Turkish, thus the readers should handle the item pool accordingly. 
Table 2. Item pool for Academic Intellectual Capital Scale (31 items).

\begin{aligned} & \hline$\# \multicolumn{1}{c}{$ Item in Turkish } \\ & \hline 1 Üniversitemizde bilimsel araştırmaya \\ & odaklanmış güçlü bir akademik kültür vardır. \\ & 2 Üniversitemizdeki öğretim elemanları, \\ & öğrencileri girişimciliğe teşvik eder. \\ & 3 Üniversitemizdeki öğretim elemanları, yüksek \\ & akademik niteliklere sahiptir. \\ & 4 Üniversitemiz, verilen eğitim içeriğini \\ & destekleyecek nitelikte dijital donanıma sahiptir. \\ & 5 Üniversitemizdeki öğrenciler, birbirlerinin \\ & fikirlerine değer verir. \\ & 6 Üniversitemiz, alanlarının en başarılı öğretim \\ & elemanlarına sahiptir. \\ & 7 Üniversitemiz, verilen eğitim içeriğini \\ & destekleyecek nitelikte bina, donatı, vb. fiziki \\ & olanaklara sahiptir. \\ & 8 Üniversitemizde karar verilirken dış paydaşların \\ & (çevre, yerel yönetimler, iş dünyası vb.) fikirleri \\ & dikkate alınır. \end{aligned}

9 Üniversitemizde yeterli sayıda öğretim elemanı görev yapar.

10 Üniversitemizde ihtiyaçlara cevap verecek nitelikte bir bilgi yönetim sistemi (ders seçimi, not takibi vb.) kullanılır.

11 Üniversitemizde karar verilirken mezun öğrencilerin fikirleri dikkate alınır.

12 Üniversitemizdeki öğretim elemanları, çalışmalarını iş birliği içerisinde yürütür.

13 Üniversitemizdeki kütüphane olanakları yeterlidir.

14 Üniversitemizin, iş dünyasında faaliyet gösteren kurumlarla iş birliği protokolleri vardır.

15 Üniversitemiz, ihtiyaca cevap verecek nitelikte bir e-öğrenme platformuna sahiptir.

16 Üniversitemizin, sektördeki kuruluşlarla imzalanmış mezun işe alım protokolleri vardır.

17 Üniversitemizin başka üniversitelerle iş birliği protokolleri vardır.

18 Üniversitemiz bünyesinde işlevsel bir teknoloji transfer birimi vardır.

19 Üniversitemizde, bilimsel anlayışı topluma yaymaya yönelik etkinlikler düzenlenir.

20 Üniversitemizde farklı kültürel birikimleri olan kişiler uyum içinde çalışır.
There is a strong academic culture focused on scientific research in our university.

Faculty staff in our university leads students in entrepreneurship.

Faculty staff in our university has high academic qualifications.

Our university has the digital equipment to support the content of the education it provides. Students in our university value each other's ideas.

Our university has the most successful faculty staff in their fields.

Our university has physical facilities such as buildings and hardware to support the content of the education it provides.

Opinions of external stakeholders (environment, local authorities, business world, etc.) are taken into account in decision-making in our university.

There is a sufficient number of faculty staff in our university.

An information management system (for course selection, academic record tracking, etc.) that satisfies the needs is used in our university. Opinions of alumni are taken into account in decision-making in our university.

The faculty staff carries out their studies in cooperation in our university.

Library facilities are sufficient in our university.

Our university has cooperation protocols with institutions in the business world.

Our university has an e-learning platform that satisfies the needs.

Our university has recruitment protocols with institutions in the sector for the graduates.

Our university has cooperation protocols with other universities.

Our university has a functional technology transfer unit.

Activities for disseminating scientific perspective to society are organized in our university.

People with diverse cultural backgrounds work in harmony in our university. 
Table 2. Continued.

\begin{tabular}{|c|c|}
\hline Item in Turkish & English Translation \\
\hline $\begin{array}{l}21 \text { Üniversite yönetimi, bilgiye kolay ulaşım } \\
\text { olanakları sunar. }\end{array}$ & $\begin{array}{l}\text { The university administration offers easy access } \\
\text { to information. }\end{array}$ \\
\hline $\begin{array}{l}22 \text { Üniversitemizde çevre sorumluluğuna ilişkin } \\
\text { etkinlikler düzenlenir. }\end{array}$ & $\begin{array}{l}\text { Activities related to environmental } \\
\text { responsibility are organized in our university. }\end{array}$ \\
\hline $\begin{array}{l}23 \text { Üniversitemizdeki bilgi yönetim sistemi (ders } \\
\text { seçimi, not takibi vb.), öğretim elemanları } \\
\text { tarafından etkin bir şekilde kullanılır. }\end{array}$ & $\begin{array}{l}\text { The information management system (for course } \\
\text { selection, academic record tracking, etc.) in our } \\
\text { university is effectively used by the faculty } \\
\text { members. }\end{array}$ \\
\hline $\begin{array}{l}24 \text { Üniversitemiz, yeni iş girişimi (start-up) } \\
\text { firmalarını destekler. }\end{array}$ & Our university supports start-up companies. \\
\hline $\begin{array}{l}25 \text { Üniversitemizdeki öğretim elemanları, } \\
\text { üniversitemizin kurumsal hedeflerini } \\
\text { gerçekleştirmek için çaba sarf eder. }\end{array}$ & $\begin{array}{l}\text { The faculty staff strives for achieving the } \\
\text { corporate objectives of our university. }\end{array}$ \\
\hline $\begin{array}{l}26 \text { Üniversitemizdeki bilgi yönetim sistemi (ders } \\
\text { seçimi, not takibi vb.), öğrenciler tarafından } \\
\text { etkin bir şekilde kullanılır. }\end{array}$ & $\begin{array}{l}\text { The information management system (course } \\
\text { selection, academic record tracking, etc.) in our } \\
\text { university is effectively used by the students. }\end{array}$ \\
\hline $\begin{array}{l}27 \text { Üniversitemizdeki öğretim elemanları, } \\
\text { öğrencilerden gelen geri bildirimlere önem verir. }\end{array}$ & $\begin{array}{l}\text { The faculty staff at our university value the } \\
\text { feedback from the students. }\end{array}$ \\
\hline $\begin{array}{l}28 \text { Üniversitemizdeki öğrenciler, yaşadıkları } \\
\text { sorunları yöneticilere açık bir biçimde dile } \\
\text { getirebilir. }\end{array}$ & $\begin{array}{l}\text { The students at our university can overtly utter } \\
\text { the problems they face to the administrators. }\end{array}$ \\
\hline $\begin{array}{l}29 \text { Üniversitemiz, mezun öğrencileriyle irtibat } \\
\text { halindedir. }\end{array}$ & Our university keeps in contact with the alumni. \\
\hline $\begin{array}{l}30 \text { Üniversitemiz, özgün fikirleriyle bilinen öğretim } \\
\text { elemanlarına sahiptir. }\end{array}$ & $\begin{array}{l}\text { Our university has faculty staff known for their } \\
\text { peculiar ideas. }\end{array}$ \\
\hline $\begin{array}{l}31 \text { Üniversitemizdeki öğretim elemanları, } \\
\text { öğrencileri ekip çalışması yapmaya teşvik eder. }\end{array}$ & $\begin{array}{l}\text { The faculty staff at our university encourage } \\
\text { students for teamwork. }\end{array}$ \\
\hline
\end{tabular}

\subsubsection{Data collection}

At this stage, data are collected using a draft scale. Once the construct and the content of the scale are evaluated as satisfactory, it is inferred that the draft scale is ready for data collection (Büyüköztürk et al., 2020; DeVellis, 2017; Johnson \& Morgan, 2016). Psychometric aspects of the scale are determined depending on the data collected at this stage (Irwing \& Hughes, 2018; Netemeyer et al., 2003).

Data were collected in two steps. First, the draft scale was used and 538 participants were reached. Using the data from the first step, EFA was conducted and the number of the items reduced. Second, using the final version of the scale depending on the EFA results, another 492 participants were reached and data collected for conducting CFA.

\subsubsection{Evaluation of psychometric aspects of the scale}

Once data are gathered, scale is shaped using statistical techniques at this stage (Büyüköztürk et al., 2020). As it covers validity and reliability analyses, it is possible to call this stage the heart of the scale development process (DeVellis, 2017). Mainly, two types of analyses were followed at this stage: EFA and CFA. 


\subsection{Data Analysis}

R (version 4.1.2) (R Core Team, 2021) and RStudio (version 2021.09.1 build 372) (RStudio Team, 2021) were used to analyze the data. data.table (Dowle \& Srinivasan, 2020), dplyr (Wickham et al., 2020), EFAtools (Steiner \& Grieder, 2020), EFA.dimensions (O'Connor, 2020), lavaan (Rosseel, 2012), psych (Revelle, 2020), rela (Chajewski, 2009), semTools (Jorgensen et al., 2021), ShinyItemAnalysis (Martinková \& Drabinová, 2018), QuantPsych (Fletcher, 2015) and sirt (Robitzsch, 2021) packages were used in the analyses.

\section{FINDINGS}

Findings of EFA, CFA and reliability analyses are presented in this section.

\subsection{Exploratory Factor Analysis}

With the help of EFA, it is possible to reduce the number of items in a scale, thus variance explained by the scale can be maximized (Netemeyer et al., 2003). EFA is used for determining underlying non-observable factor structures through observable variables (Hayashi \& Yuan, 2010). In order to determine the factorial structure of the Academic Intellectual Capital Scale, EFA was conducted following the five-step model proposed by Williams et al. (2010).

\subsubsection{Checking the data for suitability}

In order to determine if the data are suitable for EFA, its factorability should be checked first. Field (2018) draws attention that the correlation coefficient between the variables shouldn't be lower than .30 and should not exceed .80 . The correlation matrix was investigated and it was observed that there was no correlation coefficient above .80 or below .30 between the variables. Another way of determining suitability for factoring of data is checking the anti-image correlation matrix. Şencan (2005) puts forward that elements that are off-diagonal in the antiimage correlation matrix should be below .30 and diagonal elements of the matrix should be above .50. The anti-image correlation matrix was obtained using rela package (Chajewski, 2009). Examining the anti-image correlation matrix showed that all diagonal elements were above .50 and off-diagonal elements were below .30 indicating that the data were suitable for factorability.

EFA is a method that depends on Pearson product-moment correlation and it assumes that the data are normally distributed. For this reason, violation of this assumption holds potential to affect the EFA results in an unintended way (Watkins, 2021). Also, Field (2018) and Şencan (2005) emphasize that in order to obtain generalizable results from EFA, normal distribution of data is essential. Tabachnick and Fidell (2014) propose that skewness and kurtosis are indicators of univariate normal distribution of data. Şencan (2005) puts forwards that skewness and kurtosis of each item should be evaluated individually to check univariate normality. Leech et al. (2015) state that skewness and kurtosis should be between +1 and -1 to define data as normally distributed in terms of univariate normality. To check univariate normality, skewness and kurtosis values of each item were calculated using psych package (Revelle, 2020). It was found out that skewness ranged between -.82 and .10 while kurtosis ranged between -.70 and .61. Depending on these results it is possible to say that the univariate normality assumption was met. Multivariate normality was checked through multivariate skewness and multivariate kurtosis tests by making use of QuantPsych package (Fletcher, 2015). Multivariate normality tests resulted in significant $p$ value meaning that multivariate normality was violated.

Bartlett Sphericity Test and Kaiser-Meyer-Olkin (KMO) Test are other ways of checking the suitability of data for EFA. With the help of these two tests, the factorability of the data is determined (Carpenter, 2018). Bartlett Sphericity Test is expected to be statistically significant, and KMO is expected to be above .50 (Field, 2018; Field et al., 2012). Using EFAtools package Bartlett Sphericity Test and KMO Test were conducted (Steiner \& Grieder, 2020). Bartlett 
Sphericity Test was found to be statistically significant $\left(\chi^{2}(465)=10715, p=.000\right)$ and KMO was .966. These results showed that the data are suitable for factorability, thus for EFA.

\subsubsection{Selection of factor extraction method}

There are various factor extraction methods in EFA such as image analysis, principal component analysis, principal axis factoring, maximum likelihood and so on (Watkins, 2021). According to Fabrigar et al. (1999) principal axis factoring (PAF) has advantage of requiring no distributional assumptions. Since multivariate normality assumptions wasn't met, it was decided to use PAF as the factor extraction method.

\subsubsection{Determining the number of factors}

EFA aims to reduce multiple items to fewer common structures. In scale development, it is important to determine the number of underlying factors as it is expected to reach similar results with the same scale on different samples. There are several techniques in determining the number of factors such as Kaiser rule (eigenvalue over 1), visually interpreting scree plot, parallel analysis and Velicer's Minimum Average Partial (MAP) Test (Costello \& Osborne, 2005; Netemeyer et al., 2003; Preacher et al., 2013; Williams et al., 2010).

Williams et al. (2010) emphasize that using multiple techniques for determining the number of factors should be preferred to get better results. In this study, it was decided to use the Kaiser rule, parallel analysis and MAP Test together to decide on the number of factors to extract.

Eigenvalues of variance explained were calculated and it was observed that there were three factors with eigenvalue over 1. Parallel analysis was also interpreted using psych package (Revelle, 2020). Parallel analysis plot is shown in Figure 1. Interpretation of plot in Figure 1 shows that the scale might have 2 factors.

Figure 1. Scree plot for parallel analysis.

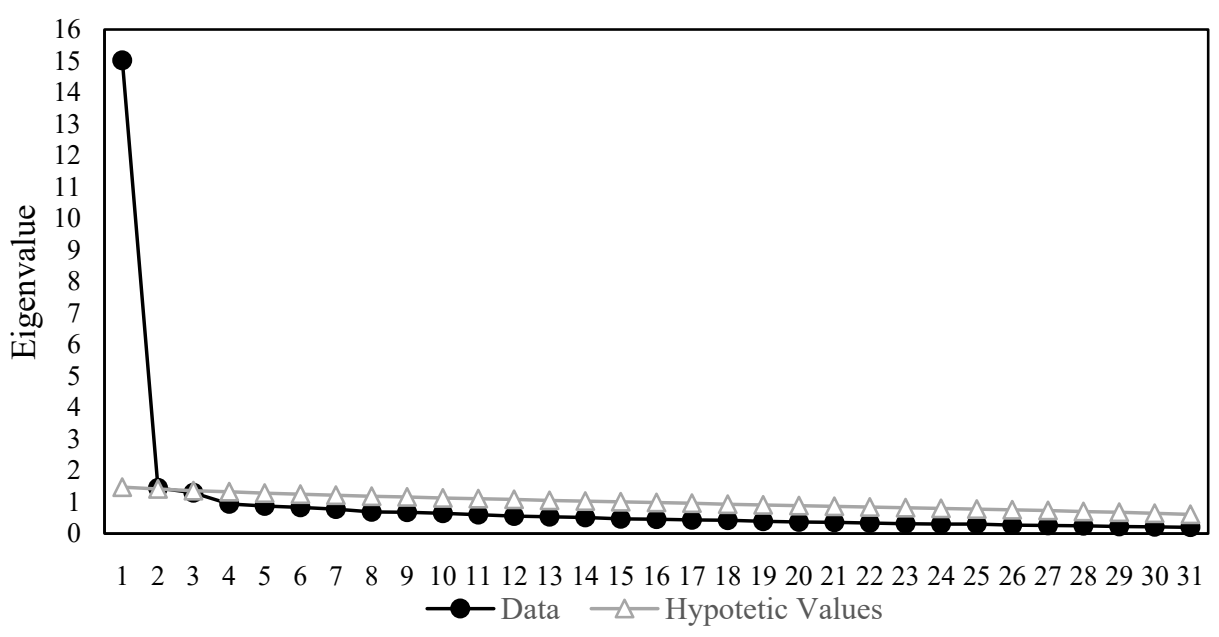

Another empirical way of determining the number of factors is the MAP Test. In this test, the partial correlation matrix is calculated after the extraction of each of the factors. The average of partial correlations is calculated for each matrix. When the appropriate number of factors is reached, it is expected to have the minimum average (Watkins, 2021). MAP Test was conducted using EFA.dimensions package (O'Connor, 2020). The results of the MAP Test are shown in Table 3.

Table 3 presents evidence that average squared partial correlation and $4^{\text {th }}$ power partial correlation decreased until reaching the third factor and started increasing after it. Depending on the results of the MAP Test, it is possible to state that the scale has three factors. 
Table 3. Map Test results.

\begin{tabular}{ccccccccc}
\hline & $\mathrm{PC}^{2^{*}}$ & $\mathrm{PC}^{4^{* *}}$ & & $\mathrm{PC}^{2^{*}}$ & $\mathrm{PC}^{4^{* *}}$ & & $\mathrm{PC}^{2^{*}}$ & $\mathrm{PC}^{4^{* *}}$ \\
\hline 0 & .22147 & .05393 & 11 & .02434 & .00233 & 22 & .09020 & .02355 \\
1 & .01177 & .00042 & 12 & .02713 & .00261 & 23 & .10457 & .03051 \\
2 & .01101 & .00035 & 13 & .03015 & .00310 & 24 & .12499 & .03851 \\
3 & .00992 & .00034 & 14 & .03324 & .00395 & 25 & .14970 & .05581 \\
4 & .01089 & .00036 & 15 & .03716 & .00440 & 26 & .18220 & .07630 \\
5 & .01194 & .00041 & 16 & .04208 & .00549 & 27 & .23538 & .11878 \\
6 & .01320 & .00057 & 17 & .04860 & .00674 & 28 & .33232 & .20348 \\
7 & .01474 & .00074 & 18 & .05527 & .00878 & 29 & .48390 & .35518 \\
8 & .01653 & .00095 & 19 & .06202 & .01087 & 30 & 1.00000 & 1.00000 \\
9 & .01879 & .00124 & 20 & .06918 & .01416 & & & \\
10 & .02099 & .00184 & 21 & .07845 & .01847 & & & \\
\hline
\end{tabular}

* Squared partial correlation

${ }^{* *} 4^{\text {th }}$ power partial correlation

Kaiser rule, parallel analysis results and the result of MAP test were evaluated together. While parallel analysis pointed out 2 factors, Kaiser rule and MAP test indicated 3 factors. Depending on the empirical results and literature review, it is inferred that the scale had three factors.

\subsubsection{Selection of rotational method}

In order to simplify the data structure and to interpret the data structure easily, rotational methods are used (Costello \& Osborne, 2005; Motta, 2017). Basically, there are two types of rotational methods: oblique and orthogonal. When correlation is expected to be between factors, oblique methods are used and oblique rotational methods allow reaching statistically accurate factor structures (Field, 2018; Motta, 2017; Schmitt, 2011; Williams et al., 2010). Although there are various oblique rotational methods, Direct Oblimin and Promax are the prominent ones (Brody, 2017). Besides, Costello and Osborne (2005) put forward that it is not always possible to draw a strict line between the issues in fields such as education and psychology. Depending on the literature review, the structure of academic intellectual capital was inferred to arise from correlated elements. As a result, it was decided to use Promax oblique rotational method.

\subsubsection{Interpretation}

At this stage, items of the factors are determined and the factors are named (Williams et al., 2010). Factors are identified depending on factor loadings of the items (Johnson \& Morgan, 2016). Tabachnick and Fidell (2014) propose that the lower bound for an item loading to be accepted is .32 whereas Johnson and Morgan (2016) put forward that the lower bound should be .40. In this study, it was decided that the lower bound for item loading would be .40 and it was decided to remove any items lower than that value from the scale. Also, in some cases, some of the items might have loading on more than one factor (Welch, 2010). Overlapping items with less than .20 difference in factor loadings were also decided to remove from the scale (Child, 2006). EFA is conducted using psych package (Revelle, 2020).

EFA was conducted and items with lower than .40 item loading were removed from the scale (respectively items 13, 9, 5, 28, 8, 20, 12 and 25). Subsequently, overlapping items were also removed from the scale (respectively items 27, 29 and 21). After each item removal, the analysis was repeated. In the end, there were 20 items left for EFA. Bartlett Sphericity Test and KMO test were also carried out with 20 items. The results of Bartlett Sphericity Test were statistically significant $\left(\chi^{2}(190)=6523.40, p=.000\right)$ and $\mathrm{KMO}$ was .949 indicating that data of 20 items were suitable for EFA. The results of EFA are presented in Table 4. 
Table 4. EFA results.

\begin{tabular}{ccccc}
\hline \multirow{2}{*}{ Items } & \multicolumn{3}{c}{ Factors } & \multirow{2}{*}{ Communalities } \\
\cline { 2 - 4 } & 1 & 2 & 3 & \\
\hline Item 03 & .89 & .04 & -.14 & .67 \\
Item 06 & .79 & -.09 & .07 & .60 \\
Item 30 & .74 & 0 & .09 & .66 \\
Item 02 & .68 & .11 & -.04 & .54 \\
Item 31 & .60 & .02 & .14 & .53 \\
Item 01 & .50 & .19 & .09 & .51 \\
Item 10 & .02 & .89 & -.15 & .64 \\
Item 26 & .02 & .72 & 0 & .55 \\
Item 04 & .02 & .69 & .06 & .56 \\
Item 07 & .03 & .65 & .02 & .46 \\
Item 23 & .11 & .65 & .07 & .60 \\
Item 15 & -.02 & .55 & .25 & .54 \\
Item 24 & .08 & -.18 & .87 & .64 \\
Item 16 & -.12 & 0 & .87 & .62 \\
Item 18 & -.11 & .23 & .66 & .59 \\
Item 17 & -.01 & .05 & .65 & .46 \\
Item 22 & .20 & -.05 & .63 & .57 \\
Item 19 & .18 & .05 & .59 & .58 \\
Item 14 & -.04 & .24 & .54 & .50 \\
Item 11 & .17 & .02 & .48 & .39 \\
\hline Variance & 17.74 & 17.40 & 21.01 & \\
Explained (\%) & & & &
\end{tabular}

Table 4 shows that items 3,6, 30, 2, 31 and 1 were under factor 1 (factor loadings varied between .89 and .50), items 10, 26, 4, 7, 23 and 15 were under factor 2 (factor loadings varied between .89 and .55), and items 24, 16, 18, 17, 22, 19, 14 and 11 were under factor 3 (factor loadings varied between .87 and .48). Factor number 1 explained $17.74 \%$, factor number 2 explained $17.40 \%$ and factor number 3 explained $21.01 \%$ of the total variance. The scale explained $56.15 \%$ of total variance.

Items in the factors were evaluated and, factor number 1 with 6 items was named Academic Human Capital, factor number 2 with 6 items was named Academic Structural Capital, and factor number 3 with 8 items was named Academic Relational Capital. Holistically, it is possible to state that Academic Intellectual Capital Scale is composed of three factors and 20 items, all of which are in affirmative form.

Interfactor correlations provided by $f a$ function from psych package (Revelle, 2020) are presented in Table 5.

Table 5. Interfactor correlations.

\begin{tabular}{ccccc}
\hline & $\begin{array}{c}\text { Academic Human } \\
\text { Capital }\end{array}$ & $\begin{array}{c}\text { Academic Structural Academic Relational } \\
\text { Capital }\end{array}$ & Capital \\
\hline Academic Human Capital & 1 & .690 & .728 \\
Academic Structural Capital & .690 & 1 & .735 \\
Academic Relational Capital & .728 & .735 & 1 \\
\hline
\end{tabular}

Table 5 shows that Academic Human Capital had positive interfactor correlation with Academic Structural Capital (.690) and positive interfactor correlation with Academic Relational Capital (.728). Academic Structural Capital had positive interfactor correlation with Academic Relational Capital (.735). Following that, a Pearson product-moment correlation test 
was conducted. The summary table of the correlation test was obtained by using data.table package (Dowle \& Srinivasan, 2020). The results are presented in Table 6.

Table 6. Correlation test results.

\begin{tabular}{ccccc}
\hline & $\begin{array}{c}\text { Academic Human } \\
\text { Capital }\end{array}$ & $\begin{array}{c}\text { Academic Structural Academic Relational } \\
\text { Capital }\end{array}$ & Capital \\
\hline Academic Human Capital & 1 & .675 & .718 \\
Academic Structural Capital & .675 & 1 & .715 \\
Academic Relational Capital & .718 & .715 & 1 \\
Academic Intellectual Capital & .880 & .881 & .923 \\
\hline
\end{tabular}

Table 6 shows that Academic Human Capital had statistically significant positive correlation with Academic Structural Capital $(\mathrm{r}=.675, p=.000)$; statistically significant positive correlation with Academic Relational Capital $(\mathrm{r}=.718, p=.000)$; and statistically significant positive correlation with scale total score $(\mathrm{r}=.880, p=.000)$. Academic Structural Capital had statistically significant positive correlation with Academic Relational Capital $(\mathrm{r}=.715, p=$ $.000)$; and statistically significant positive correlation with scale total score $(\mathrm{r}=.881, p=.000)$. Academic Relational Capital had statistically significant positive correlation with scale total score $(\mathrm{r}=.923, p=.000)$. It was found out that all the factors and scale total scores had statistically significant positive correlation. This result revealed that all the factors measure a similar structure.

\subsection{Confirmatory Factor Analysis}

Ullman (2014) points out that in addition to having an adequate number of participants, normal distribution of data is also important in CFA. To check univariate normality (Tabachnick \& Fidell, 2014), skewness and kurtosis values of each item were calculated using psych package (Revelle, 2020). It was found out that skewness ranged between -.89 and .63 while kurtosis ranged between -.86 and .04 . Depending on these results it is possible to infer that the data had univariate normality. Multivariate normality tests of multivariate skewness and multivariate kurtosis (Fletcher, 2015) resulted in significant $p$ value meaning that multivariate normality was violated.

In order to confirm a model in CFA, there are various parameters to check. Kline (2015) suggests that $\chi^{2}$, degree of freedom, the significance of $\chi^{2}$, RMSEA, CFI and SRMR are the minimum parameters to look for in CFA. Schermelleh-Engel et al. (2003) draw attention that there is no consensus on which parameters to control in CFA. On the other hand, Kline (2015) emphasizes that each parameter represents a different aspect of the scale under investigation and there is no single parameter to confirm the proposed model.

Brown (2015) puts forward if the data is categorical and normality assumption is violated, Maximum Likelihood estimation method should not be used in CFA. Instead, it is possible to use one of several estimators such as ULS, WLS and WLSMV. Irwing et al. (2018) and Schmitt (2011) propose that WLSMV estimator should be used with categorical data. In addition, Li (2016) and Bagheri and Saadati (2021) assert that WLSMV has no assumptions regarding distribution of the data. In this respect, CFA with WLSMV estimator was conducted using lavaan package (Rosseel, 2012). Fit indices and the results of CFA are presented in Table 7. 
Table 7. Fit indices and CFA results.

\begin{tabular}{cccc}
\hline Parameter & Result & Perfect Fit & Acceptable Fit \\
\hline$\chi^{2} / \mathrm{df}$ & 2.354 & $0 \leq \chi^{2} / d f \leq 2$ & $2 \leq \chi^{2} / d f \leq 5$ \\
RMSEA & .053 & $0 \leq \mathrm{RMSEA} \leq .05$ & $.05<\mathrm{RMSEA} \leq .08$ \\
SRMR & .031 & $0 \leq \mathrm{SRMR} \leq .05$ & $.05<\mathrm{SRMR} \leq .10$ \\
NFI & .844 & $.95 \leq \mathrm{NFI} \leq 1.00$ & $.90 \leq \mathrm{NFI}<.95$ \\
NNFI & .890 & $.97 \leq \mathrm{NNFI} \leq 1.00$ & $.90 \leq \mathrm{NNFI}<.97$ \\
CFI & .903 & $.97 \leq \mathrm{CFI} \leq 1.00$ & $.95 \leq \mathrm{CFI}<.97$ \\
GFI & .998 & $.95 \leq \mathrm{GFI} \leq 1.00$ & $.80 \leq \mathrm{GFI}<.95$ \\
AGFI & .997 & $.90 \leq \mathrm{AGFI} \leq 1.00$ & $.80 \leq \mathrm{AGFI}<.90$ \\
\hline
\end{tabular}

Source: Awang (2012), Byrne (2016), Doll et al. (1994), Forza and Filippini (1998), Greenspoon and Saklofske (1998), Hooper et al. (2008), Hu and Bentler (1999), Schermelleh-Engel et al. (2003), Schumacker and Lomax (2016), Segars and Grover (1993), Steiger (2007)

The CFA results showed that $\chi^{2}=393.223$, degree of freedom was 167 and significance was $p$ $=.000$. Hair et al. (2018) put forward that scales having 12 to 30 items with over 250 participants are expected to have a statistically significant $p$ value for $\chi^{2}$. CFA results also revealed that $\chi^{2} / \mathrm{df}$ was $2.354<5$ (Doll et al., 1994; Hooper et al., 2008), RMSEA was .053<.08 (Hooper et al., 2008; Schermelleh-Engel et al., 2003; Schumacker \& Lomax, 2016), SRMR was .031<.05 (Byrne, 2016; Doll et al., 1994; Schumacker \& Lomax, 2016), GFI was .998 > .80 (Forza \& Filippini, 1998; Greenspoon \& Saklofske, 1998) and AGFI was .997 > .80 (Forza \& Filippini, 1998; Segars \& Grover, 1993). It also showed that NFI was .844 which was not far from the cut value (.90) proposed by Schermelleh-Engel et al. (2003), NNFI was .890 which was not far from the cut value (.90) proposed by Awang (2012) and Forza and Filippini (1998) and CFI was .903 which was not far from the cut value (.95) proposed by $\mathrm{Hu}$ and Bentler (1999). Evaluated together, CFA confirmed the proposed model for Academic Intellectual Capital Scale. Measurement model for the scale is presented in Figure 2.

Figure 2. Measurement model for the Academic Intellectual Capital Scale.

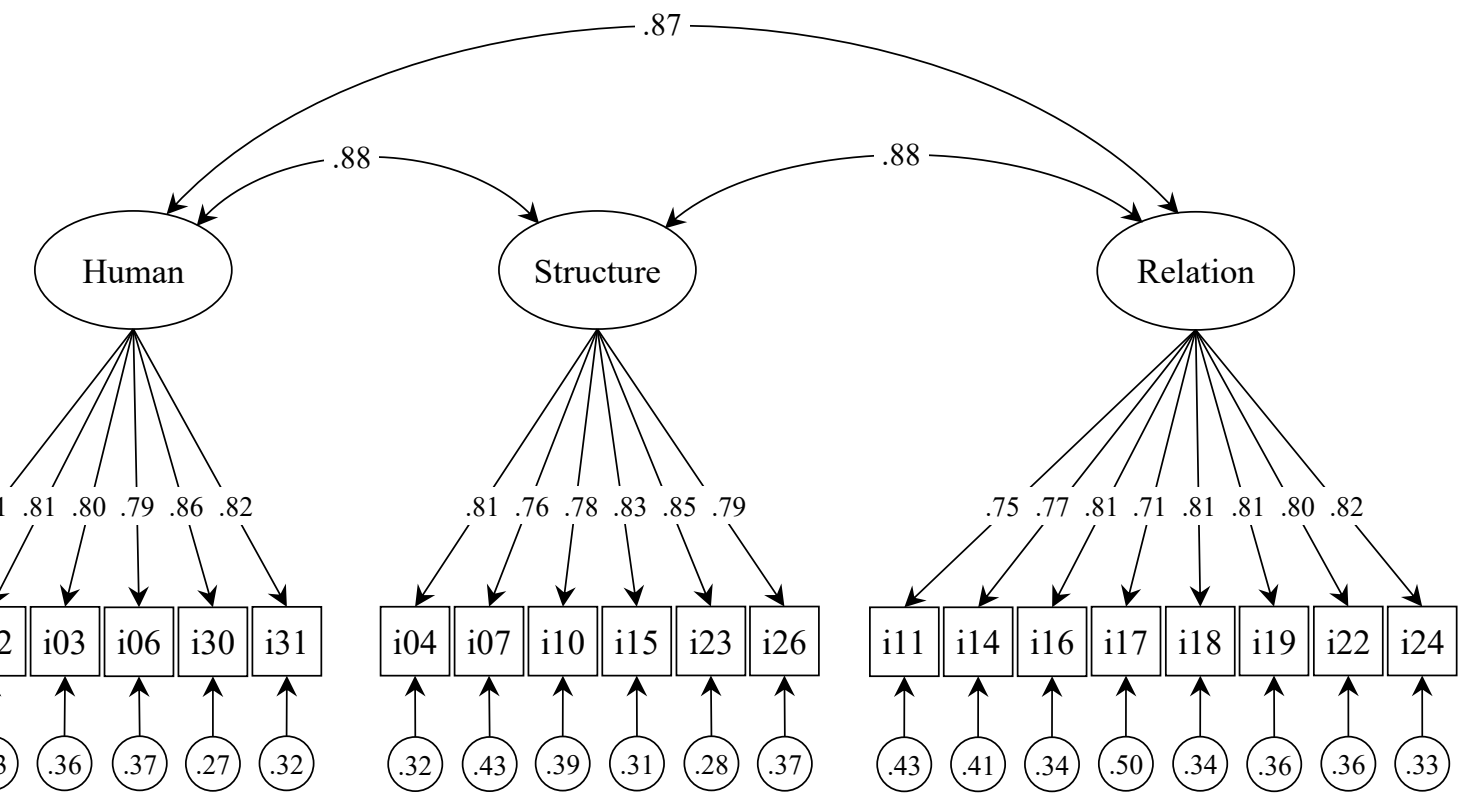


Figure 2 shows the factor loadings of the items. None of the error variances were linked. The figure also demonstrates the confirmed model of Academic Intellectual Capital Scale consisting of Academic Human Capital, Academic Structural Capital and Academic Relational Capital subdimensions.

\subsection{Reliability}

In order to test the reliability of the scores obtained from Academic Intellectual Capital Scale, reliability coefficient was calculated, independent samples t-test was conducted between upper $27 \%$ scores and lower $27 \%$ scores, and item-total, item-remainder correlation was calculated. Reliability analyses were carried out on a sample of 1030 participants by combining EFA and CFA data sets $(538+492)$.

Field (2018) states that Cronbach's Alpha $(\alpha)$ is the most widely used internal consistency coefficient for scales. However, Osburn (2000) suggests that stratified alpha $\left(\alpha_{s}\right)$ provides more accurate results in terms of reliability. On the other hand, Rae (2007) draws attention that both alpha and stratified alpha should be calculated. In this perspective, it was decided to calculate stratified alpha for whole scale in addition to Cronbach's Alpha. Additionally, Composite Reliability (cR) and McDonald's Omega $(\omega)$ are other measures for internal consistency (Irwing $\&$ Hughes, 2018; Netemeyer et al., 2003). While Hair et al. (2018) put forward that cR is a more robust way of calculating internal consistency, Irwing and Hughes (2018) claim that $\omega$ is a more exact solution. McDonald's Omega was calculated using pych package (Revelle, 2020), Cronbach's Alpha and Composite Reliability were calculated using semTools package (Jorgensen et al., 2021) and stratified alpha was calculated using sirt package (Robitzsch, 2021). Calculated $\alpha, \alpha_{\mathrm{s}}, \mathrm{cR}$ and $\omega$ coefficients are presented in Table 8.

Table 8. Internal reliability test results.

\begin{tabular}{lcccc}
\hline & $\begin{array}{c}\text { Cronbach's } \\
\text { Alpha }(\alpha)\end{array}$ & $\begin{array}{c}\text { Stratified } \\
\text { Alpha }\left(\alpha_{\mathrm{s}}\right)\end{array}$ & $\begin{array}{c}\text { Composite } \\
\text { Reliability }(\mathrm{cR})\end{array}$ & $\begin{array}{c}\text { MacDonald's } \\
\text { Omega }(\omega)\end{array}$ \\
\hline Academic Human Capital & .906 & & .905 & .904 \\
Academic Structural Capital & .898 & & .897 & .896 \\
Academic Relational Capital & .913 & & .914 & .909 \\
Total Score & .957 & .963 & .962 & .963 \\
\hline
\end{tabular}

Alpha over .80 presents evidence for a very good internal consistency whereas alpha over .90 is an indicator of perfect consistency (DeVellis, 2017; Kline, 2015). On the other hand, Composite Reliability over .70 (Hair et al., 2018) and McDonald's Omega over .80 (Feißt et al., 2019) demonstrate that internal consistency of the scale is ensured. Scores on Table 8 indicate that the Academic Intellectual Capital Scale had a high internal consistency.

In order to determine item discrimination, together with item-total and item-remainder correlation, independent samples t-test between top $27 \%$ scores and bottom $27 \%$ scores were carried out. Netemeyer et al. (2003) and Dorans (2018) put forward that a low or negative itemremainder correlation coefficient is proof that the item does not serve the purpose of the scale. While Johnson and Morgan (2016) claim that items with item-remainder correlation coefficient should be above .20, Field (2018) defends that item with an item-remainder correlation coefficient below .30 should be removed from the scale. Item-total and item-remainder correlation coefficients were calculated using ShinyItemAnalysis package (Martinková \& Drabinová, 2018) and independent samples t-test between upper and lower scores were calculated using $d p l y r$ package (Wickham et al., 2020). The results are presented in Table 9. 
Table 9. Item analysis results.

\begin{tabular}{|c|c|c|c|c|c|c|c|c|c|c|}
\hline Dimension & Item & $r_{i t}$ & $p$ & $\mathrm{r}_{\text {ir }}$ & $p$ & $\begin{array}{c}\text { Top } 27 \% \\
\bar{X}\end{array}$ & $\begin{array}{c}\text { Bottom } 27 \% \\
\bar{X}\end{array}$ & $t$ & $d f$ & $p$ \\
\hline \multirow{6}{*}{$\begin{array}{c}\text { Academic } \\
\text { Human } \\
\text { Capital }\end{array}$} & i01 & .744 & .000 & .712 & .000 & 4.46 & 2.25 & 42.115 & 558 & .000 \\
\hline & i02 & .735 & .000 & .704 & .000 & 4.45 & 2.31 & 41.686 & 558 & .000 \\
\hline & i03 & .735 & .000 & .703 & .000 & 4.72 & 2.49 & 43.559 & 558 & .000 \\
\hline & i06 & .728 & .000 & .693 & .000 & 4.50 & 2.10 & 46.153 & 558 & .000 \\
\hline & $\mathrm{i} 30$ & .783 & .000 & .756 & .000 & 4.41 & 2.24 & 40.372 & 558 & .000 \\
\hline & i31 & .745 & .000 & .714 & .000 & 4.47 & 2.31 & 40.887 & 558 & .000 \\
\hline \multirow{6}{*}{$\begin{array}{c}\text { Academic } \\
\text { Structural } \\
\text { Capital }\end{array}$} & i04 & .749 & .000 & .717 & .000 & 4.50 & 2.19 & 42.934 & 558 & .000 \\
\hline & i07 & .689 & .000 & .651 & .000 & 4.47 & 2.20 & 44.092 & 558 & .000 \\
\hline & i10 & .722 & .000 & .687 & .000 & 4.55 & 2.23 & 43.955 & 558 & .000 \\
\hline & i15 & .759 & .000 & .726 & .000 & 4.48 & 2.03 & 47.120 & 558 & .000 \\
\hline & i23 & .779 & .000 & .750 & .000 & 4.53 & 2.30 & 42.549 & 558 & .000 \\
\hline & i26 & .724 & .000 & .690 & .000 & 4.59 & 2.40 & 41.250 & 558 & .000 \\
\hline \multirow{8}{*}{$\begin{array}{c}\text { Academic } \\
\text { Relational } \\
\text { Capital }\end{array}$} & i11 & .695 & .000 & .653 & .000 & 4.24 & 1.49 & 69.739 & 558 & .000 \\
\hline & i14 & .729 & .000 & .695 & .000 & 4.42 & 2.13 & 45.764 & 558 & .000 \\
\hline & i16 & .752 & .000 & .719 & .000 & 4.26 & 1.66 & 67.259 & 558 & .000 \\
\hline & i17 & .678 & .000 & .643 & .000 & 4.36 & 2.32 & 38.895 & 558 & .000 \\
\hline & i18 & .763 & .000 & .733 & .000 & 4.30 & 1.90 & 54.482 & 558 & .000 \\
\hline & i19 & .775 & .000 & .746 & .000 & 4.36 & 1.90 & 55.220 & 558 & .000 \\
\hline & i22 & .758 & .000 & .726 & .000 & 4.47 & 2.10 & 44.905 & 558 & .000 \\
\hline & i24 & .759 & .000 & .728 & .000 & 4.25 & 1.75 & 68.127 & 558 & .000 \\
\hline
\end{tabular}

Table 9 shows that item-total correlation coefficients $\left(\mathrm{r}_{\mathrm{it}}\right)$ varied between .678 and .783 , itemremainder correlation coefficients $\left(\mathrm{r}_{\mathrm{ir}}\right)$ varied between .643 and .756 , and all the values obtained were statistically significant. In addition, Table 9 demonstrates that there is a statistically significant difference between the upper $27 \%$ scores and the lower $27 \%$ scores in favor of the upper segment for all the items. Reviewed together, results of item analyses presented evidence that the Academic Intellectual Capital Scale consisted of discriminating items.

\section{DISCUSSION and CONCLUSION}

In this study, perceptions of students regarding the academic intellectual capital of higher education institutions were in focus. Determining student perceptions in terms of academic intellectual capital holds importance as the students constitute both the input and the output of the educational process the higher education institutions provide. From this perspective, it is expected that this study will contribute to the literature. In this study, a scale with a valid structure for measuring academic intellectual capital levels of higher education institutions depending on student perceptions was developed. Item pool consisting of 90 items for the scale was formed after an extensive literature review. 4 language experts evaluated the initial item pool for language suitability and a panel of 13 scholars evaluated the items to ensure content validity. 59 items were eliminated depending on the opinions of field experts. The draft item pool had 31 items.

Data were collected in two stages. In the first stage, 538 students from 96 universities participated in the study and the draft item pool consisting of 31 items was used. In the second stage, 492 students who didn't take part in the first stage from 112 universities participated in the study. 
In the first stage, the main aim was to reveal scale structure through EFA. Results of EFA revealed that Academic Intellectual Capital Scale had three factors. These were Academic Human Capital, Academic Structural Capital and Academic Relational Capital. There were 6 items in the Academic Human Capital factor, 6 items in the Academic Structural Capital factor and 8 items in the Academic Relational Capital factor. The Academic Human Capital factor explained $17.74 \%$ of the total variance, the Academic Structural Capital explained $17.40 \%$ of the total variance and the Academic Relational Capital factor explained $21.01 \%$ of the total variance. The total variance explained by the scale was $56.15 \%$. In the second stage of the study, the theoretical model proposed by the results of EFA was validated by CFA. Results of CFA confirmed that Academic Intellectual Capital Scale consisted of three factors and 20 items, all in affirmative form. The scale is structured in 5-point Likert-type with options ranging from (1) not true at all to (5) completely true. A score between 20 and 100 can be obtained from the scale. The higher the obtained score, the better the perception of students regarding the academic human capital, academic structural capital and academic relational capital, and vice versa.

The reliability of the scores obtained from the scale was tested by Cronbach's Alpha, stratified alpha, Composite Reliability and McDonald's Omega. Cronbach's Alpha for Academic Human Capital score was .906, for Academic Structural Capital score was .898, for Academic Relational Capital score was .913, and for the total score was .957. Stratified alpha was .963 . Composite Reliability for Academic Human Capital score was .905, for Academic Structural Capital score was .897, for Academic Relational Capital score was .914 and for the total score was .962. McDonald's Omega for Academic Human Capital score was .904, for Academic Structural Capital score was .896, for Academic Relational Capital score was .909 and for the total score was .963 . Results of the reliability tests proved that the scale had internal consistency.

Item discrimination was inspected by calculating item-total and item-remainder correlation coefficients. In addition, a t-test was conducted between upper $27 \%$ scores and lower $\% 27$ scores for all the items. Item-total and item-remainder correlations revealed that all the items in the scale served the purpose of the scale. Results of the t-test showed that there was a statistically significant difference between upper $27 \%$ scores and lower $27 \%$ scores in favor of upper scores. Items in the scale were proved to be discriminating. The final form of the Academic Intellectual Scale is provided in Appendix.

Managing academic intellectual capital is among the inevitable outcomes of the knowledge era. It was observed that the studies in the literature on measurement tools regarding academic intellectual capital were limited. The Academic Intellectual Capital Scale developed in this study was statistically proven to be a measurement tool with a valid structure. In this context, it is expected the Academic Intellectual Capital Scale contributes to the literature. With the help of this scale, administrators of higher education institutions may have the opportunity to get a clearer picture of the student perceptions regarding academic intellectual capital.

It should be kept in mind that this study only covers the perceptions of the students of higher education institutions. Similar studies on perceptions of faculty staff, non-academic staff and/or administrators are suggested to be carried out to provide a more explicit view of the academic intellectual capital of higher education institutions. Also, it should be noted that the data was gathered using snowball sampling method which is one of non-probability sampling techniques. A probability sampling technique may be used in the future studies. In addition, the fact that items with loading below .40 were removed from the scale during EFA might have led to a reduced content validity. 


\section{Acknowledgments}

This study was produced from the first author's doctoral dissertation under the supervision of the second author.

\section{Declaration of Conflicting Interests and Ethics}

The authors declare no conflict of interest. This research study complies with research publishing ethics. The scientific and legal responsibility for manuscripts published in IJATE belongs to the authors. Ethics Committee Number: Marmara University, 15.02.2021, 2100042416.

\section{Authorship Contribution Statement}

Ugur Ozalp: Investigation, Resources, Visualization, Software, Formal Analysis, and Writing the original draft. Munevver Cetin: Supervision and Validation.

Orcid

Ugur OZALP (D) https://orcid.org/0000-0001-6790-5304

Munevver CETIN (D) https://orcid.org/0000-0002-1203-9098

\section{REFERENCES}

American Educational Research Association. (2014). Standards for educational and psychological testing. American Educational Research Association.

Asiaei, K., \& Jusoh, R. (2017). Using a robust performance measurement system to illuminate intellectual capital. International Journal of Accounting Information Systems, 26, 1-19. https://doi.org/10.1016/j.accinf.2017.06.003

Awang, Z. (2012). Structural equation modeling using AMOS graphic. Universiti Teknologi MARA Publication Centre (UPENA).

Ayre, C., \& Scally, A.J. (2014). Critical values for Lawshe's content validity ratio: Revisiting the original methods of calculation. Measurement and Evaluation in Counseling and Development, 47(1), 79-86. https://doi.org/10.1177/0748175613513808

Bagheri, A., \& Saadati, M. (2021). Generalized structural equations approach in the of elderly self-rated health. Journal of Physics: Conference Series, 1863(1), 1-10. https://doi.org/1 0.1088/1742-6596/1863/1/012041

Basile, C.G. (2009). Intellectual capital: The tangible assets of professional development schools. State University of New York Press.

Baş, M., Mısırdalı Yangil, F., \& Aygün, S. (2014). Entelektüel sermaye alanında yapılan lisansüstü tez çalışmalarına yönelik bir içerik analizi: 2002 - 2012 dönemi [A content analysis on the dissertations on intellectual capital: 2002 - 2021 period]. International Journal of Management Economics and Business, 10(23), 207-226. https://doi.org/10.17130/ijmeb.2014.10.23.618

Bontis, N. (1998). Intellectual capital: an exploratory study that develops measures and models. Management Decision, 36(2), 63-76. https://doi.org/10.1108/00251749810204142

Bontis, N. (2002). Managing organizational knowledge by diagnosing intellectual capital: Framing and advancing the state of the field. In N. Bontis (Ed.), World Congress on Intellectual Capital Readings (pp. 13-56). Elsevier.

Bontis, N., Crossan, M. M., \& Hulland, J. (2002). Managing an organizational learning system by aligning stocks and flows. Journal of Management Studies, 39(4), 437-469. https://doi.org/10.1111/1467-6486.t01-1-00299

Bontis, N., Keow, W.C.C., \& Richardson, S. (2000). Intellectual capital and business performance in Malaysian industries. Journal of Intellectual Capital, 1(1), 85-100. https://doi.org/10.1108/14691930010324188

Bozbura, F.T., \& Toraman, A. (2004). Türkiye'de entelektüel sermayenin ölçülmesi ile ilgili 
model çalışması ve bir uygulama [A model study of measurement intellectual capital in Turkey and an application]. ITÜ Dergisi, 3(1), 55-66. http://itudergi.itu.edu.tr/index.php /itudergisi d/article/viewFile/709/643

Brătianu, C., \& Pînzaru, F. (2015). Challenges for the university intellectual capital in the knowledge economy. Management Dynamics in the Knowledge Economy, 3(4), 609-627. https://www.managementdynamics.ro/index.php/journal/article/view/153/102

Brenca, A., \& Garleja, R. (2013). Intellectual capital in the higher education institutions of Latvia in the context of international trade. European Conference on Intellectual Capital, 495.

Brenca, A., \& Gravite, A. (2013). Intellectual capital import for the benefit of higher education. Bulgarian Comparative Education Society, 1-6.

Brody, N. (2017). Factor analysis: Rotated matrix. In M. Allen (Ed.), The SAGE encyclopedia of communication research methods (pp. 526-531). Sage Reference.

Brown, T.A. (2015). Confirmatory factor analysis for applied research. The Guilford Press.

Büyüköztürk, Ş., Kılıç Çakmak, E., Erkan Akgün, Ö., Karadeniz, Ş., \& Demirel, F. (2020). Bilimsel araştırma yöntemleri [Scientific research methods in education]. Pegem Akademi. https://doi.org/10.14527/9789944919289

Byrne, B.M. (2016). Structural equation modeling with AMOS: Basic concepts, applications, and programming. Routledge.

Cabrita, M. do R., \& Bontis, N. (2008). Intellectual capital and business performance in the Portuguese banking industry. International Journal of Technology Management, 43(13), 212-237. http://dx.doi.org/10.1504/IJTM.2008.019416

Cabrita, M. do R., \& Vaz, J.L. (2005). Intellectual capital and value creation: Evidencing in Portuguese banking industry. In D. Remenyi (Ed.), Proceedings of the European Conference on Knowledge Management, ECKM (pp. 98-106). University of Limerick.

Carpenter, S. (2018). Ten steps in scale development and reporting: A guide for researchers. Communication Methods and Measures, 12(1), 25-44. https://doi.org/10.1080/19312458 .2017 .1396583

Carson, E., Ranzijn, R., Winefield, A., \& Marsden, H. (2004). Intellectual capital: Mapping employee and work group attributes. Journal of Intellectual Capital, 5(3), 443-463. https://doi.org/10.1108/14691930410550390

Chajewski, M. (2009). rela: Scale item analysis. R package version 4.1.

Chan, K.H. (2009). Impact of intellectual capital on organisational performance: An empirical study of companies in the Hang Seng Index (Part 1). The Learning Organization, 16(1), 4-21. https://doi.org/10.1108/09696470910927641

Chang, S.C., Chen, S.S., \& Lai, J.H. (2008). The effect of alliance experience and intellectual capital on the value creation of international strategic alliances. Omega, 36(2), 298-316. https://doi.org/10.1016/j.omega.2006.06.010

Chatterji, N., \& Kiran, R. (2017). Relationship between university performance and dimensions of intellectual capital: An empirical investigation. Eurasian Journal of Educational Research, 71, 215-232. https://doi.org/10.14689/ejer.2017.71.12

Chen, J., Zhu, Z., \& Yuan Xie, H. (2004). Measuring intellectual capital: A new model and empirical study. Journal of Intellectual Capital, 5(1), 195-212. https://doi.org/10.1108/1 4691930410513003

Child, D. (2006). The essentials of factor analysis. Continuum.

Costello, A.B., \& Osborne, J.W. (2005). Best practices in exploratory factor analysis: Four recommendations for getting the most from your analysis. Practical Assessment, Research and Evaluation, 10(7).

de Castro, G.M., Verde, M.D., Sáez, P.L., \& López, J.E.N. (2010). Technological innovation: An intellectual capital based view. Palgrave Macmillan. 
de Frutos-Belizón, J., Martín-Alcázar, F., \& Sánchez-Gardey, G. (2019). Conceptualizing academic intellectual capital: Definition and proposal of a measurement scale. Journal of Intellectual Capital, 20(3), 306-334. https://doi.org/10.1108/JIC-09-2018-0152

Dean, A., \& Kretschmer, M. (2007). Can ideas be capital? Factors of production in the postindustrial economy: A review and critique. Academy of Management Review, 32(2), 573-594. https://doi.org/10.5465/AMR.2007.24351866

Delgado-Verde, M., \& Cruz-González, J. (2010). An intellectual capital-based view of technological innovation. In P. L. Sáez, G. M. de Castro, J. E. N. López, \& M. DelgadoVerde (Eds.), Intellectual capital and technological innovation: Knowledge-based theory and practice (pp. 166-193). Information Science Reference.

Demir, S. (2018). Entelektüel sermaye ile öğretmenlerin iş doyumları arasındaki ilişki üzerine bir çalışma [A study on the relationship between intellectual capital and teachers' job satisfaction]. Inönü University Journal of the Faculty of Education, 19(3), 205-215. https://doi.org/10.17679/inuefd.385908

DeVellis, R.F. (2017). Scale development: Theory and applications. Sage.

Doll, W.J., Xia, W., \& Torkzadeh, G. (1994). A confirmatory factor analysis of the end-user computing satisfaction instrument. MS Quarterly, 18(4), 453-461.

Dorans, N.J. (2018). Scores, scales, and score linking. In P. Irwing, T. Booth, \& D. J. Hughes (Eds.), The Wiley handbook of psychometric testing: A multidisciplinary reference on survey, scale and test development2 (pp. 573-605). Wiley Blackwell.

Dowle, M., \& Srinivasan, A. (2020). data.table: Extension of "data.frame."

Dzinkowski, R. (2000). The measurement and management of intellectual capital: An introduction. International Management Accounting Study, 32-36.

el Hamdi, S., Abouabdellah, A., \& Oudani, M. (2019). Industry 4.0: Fundamentals and main challenges. 12th International Colloquium on Logistics and Supply Chain Management, LOGISTIQUA 2019, 1-5. https://doi.org/10.1109/LOGISTIQUA.2019.8907280

Fabrigar, L.R., Wegener, D.T., MacCallum, R.C., \& Strahan, E. (1999). Evaluating the use of exploratory factor analysis in psychological research. Pyschological Methods, 4(3), 272299. https://doi.org/10.1037/1082-989x.4.3.272

Feißt, M., Hennigs, A., Heil, J., Moosbrugger, H., Kelava, A., Stolpner, I., Kieser, M., \& Rauch, G. (2019). Refining scores based on patient reported outcomes - statistical and medical perspectives. BMC Medical Research Methodology, 19(1), 167. https://doi.org/10.1186/ $\underline{\text { s12874-019-0806-9 }}$

Field, A. (2018). Discovering statistics using IBM SPSS Statistics (5th Editio). Sage.

Field, A., Miles, J., \& Field, Z. (2012). Discovering statistics using R. Sage.

Fink, A. (2010). Survey Research Methods. In P. Peterson, E. Baker, \& B. McGraw (Eds.), International encyclopedia of education (pp. 152-160). Elsevier.

Fitz-enz, J. (2019). The ROI of human capital: Measuring the economic value of employee performance. Amacom.

Fletcher, T.D. (2015). Package 'QuantPsyc.' https://cran.r-project.org/web/packages/QuantPs yc

Forza, C., \& Filippini, R. (1998). TQM impact on quality conformance and customer satisfaction: A causal model. International Journal of Production Economics, 55(1), 120. https://doi.org/10.1016/S0925-5273(98)00007-3

Gilbert, G.E., \& Prion, S. (2016). Making sense of methods and measurement: Lawshe's content validity index. Clinical Simulation in Nursing, 12(12), 530-531. https://doi.org/10.1016/j.ecns.2016.08.002

Görmüş, A.Ş. (2009). Entelektüel sermaye ve insan kaynaklari yönetiminin artan önemi [The growing importance of intellectual capital and human resource management]. Afyon Kocatepe University Journal of Economics and Administrative Sciences, 10(1), 57-75. 
https://acikerisim.aku.edu.tr/xmlui/handle/AKU/1310

Greenspoon, P.J., \& Saklofske, D.H. (1998). Confirmatory factor analysis of the multidimensional Students' Life Satisfaction Scale. Personality and Individual Differences, 25(5), 965-971. https://doi.org/10.1016/S0191-8869(98)00115-9

Hair, J.F., Black, W.C., Babin, B.J., \& Anderson, R.E. (2018). Multivariate data analysis. Cengage.

Han, Y., \& Li, D. (2015). Effects of intellectual capital on innovative performance: The role of knowledge-based dynamic capability. Management Decision, 53(1), 40-56. https://doi.org/10.1108/MD-08-2013-0411

Harris, V., Brett, J., Hirst, S., McClelland, Z., Phizackerley-Sugden, E., \& Brown, S. (2007). Using a quality enhancement audit approach to review provision for international students: A case study. In E. Jones \& S. Brown (Eds.), Internationalising higher education (pp. 95-106). Routledge.

Hayashi, K., \& Yuan, K.-H. (2010). Exploratory factor analysis. In N. J. Salkind (Ed.), Encyclopedia of research design (pp. 458-465). Sage.

Holland, J., \& Holland, J. (2010). Globalization of instruction: Developing intellectual capital. In P. L. Sáez, G. M. de Castro, J. E. N. López, \& M. Delgado-Verde (Eds.), Intellectual capital and technological innovation: Knowledge-based theory and practice (pp. 39-54). Information Science Reference.

Hooper, D., Coughlan, J., \& Mullen, M.R. (2008). Structural equation modelling: Guidelines for determining model fit. Electronic Journal of Business Research Methods, 6(1), 5360. https://doi.org/10.21427/D79B73

Hsu, Y.H., \& Fang, W. (2009). Intellectual capital and new product development performance: The mediating role of organizational learning capability. Technological Forecasting and Social Change, 76(5), 664-677. https://doi.org/10.1016/j.techfore.2008.03.012

Hu, L.T., \& Bentler, P.M. (1999). Cutoff criteria for fit indexes in covariance structure analysis: Conventional criteria versus new alternatives. Structural Equation Modeling, 6(1), 1-55. https://doi.org/10.1080/10705519909540118

Huang, C.C., Luther, R., \& Tayles, M. (2007). An evidence-based taxonomy of intellectual capital. Journal of Intellectual Capital, 8(3), 386-408. https://doi.org/10.1108/14691930 $\underline{710774830}$

Huang, C.C., Tayles, M., \& Luther, R. (2010). Contingency factors influencing the availability of internal intellectual capital information. Journal of Financial Reporting and Accounting, 8(1), 4-21. https://doi.org/10.1108/19852511011055916

Irwing, P., Booth, T., \& Hughes, D. J. (2018). The Wiley handbook of psychometric testing: A multidisciplinary reference on survey, scale and test development. Wiley Blackwell.

Irwing, P., \& Hughes, D.J. (2018). Test development. In P. Irwing, T. Booth, \& D. J. Hughes (Eds.), The Wiley handbook of psychometric testing: A multidisciplinary reference on survey, scale and test development (pp. 3-48). Wiley Blackwell.

Jakubowska, A., \& Rosa, A. (2014). Significance of higher education in creating of intellectual capital. Human Resources Management \& Ergonomics, 8, 48-60.

Johnson, R.L., \& Morgan, G.B. (2016). Survey scales: A guide to development, analysis, and reporting. The Guilford Press.

Jorgensen, T.D., Pornprasertmanit, S., Schoemann, A.M., \& Rosseel, Y. (2021). semTools: Useful tools for structural equation modeling.

Karakuş, M. (2008). Eğitim örgütlerinde entelektüel sermayenin yönetimi [Management of intellectual capital in educational organizations]. Milli Egitim, 178, 334-349.

Kaya, N., \& Kesen, M. (2014). İnsan kaynaklarının insan sermayesine dönüşümü: Bir literatür taramas1 [Transforming human resources into human capital: A scan of the literature]. Journal of Academic Researches and Studies, 6(10), 23-38. https://dergipark.org.tr/tr/do 
wnload/article-file/180494

Kelly, A. (2004a). The intellectual capital of schools: Analysing government policy statements on school improvement in light of a new theorization. Journal of Education Policy, 19(5), 609-629. https://doi.org/10.1080/0268093042000269180

Kelly, A. (2004b). The intellectual capital of schools - Measuring and managing knowledge responsibility and reward: Lessons from the commercial sector. Springer Science+Business Media, Inc.

Kline, R.B. (2015). Principles and practices of structural equation modelling. The Guilford Press.

Kutlu, H.A. (2009). Entelektüel sermaye: Türkiye muhasebe sisteminde raporlanabilir mi? [Intellectual capital: Can it be reported in the accounting system of Turkey?] Hacettepe University Journal of Economics and Administrative Sciences, 27(1), 235-257. https://dergipark.org.tr/en/download/article-file/302681

Lane, S., Raymond, M.R., Haladyna, T.M., \& Downing, S.M. (2016). Test development process. In S. Lane, M. R. Raymond, \& T. M. Haladyna (Eds.), Handbook of test development (pp. 3-18). Routledge.

Lawshe, C.H. (1975). A quantitative approach to content validity. Personnel Psychology, 28, 563-575. https://doi.org/10.1111/j.1744-6570.1975.tb01393.x

Leech, N.L., Barrett, K.C., \& Morgan, G.A. (2015). IBM SPSS intermediate statistics. Routledge.

Leitner, K.H. (2004). Intellectual capital reporting for universities: Conceptual background and application for Austrian universities. Research Evaluation, 13(2), 129-140. https://doi.org/10.3152/147154404781776464

Li, C.H. (2016). Confirmatory factor analysis with ordinal data: Comparing robust maximum likelihood and diagonally weighted least squares. Behavior Research Methods, 48(3), 936-949. https://doi.org/10.3758/s13428-015-0619-7

Litwin, M.S. (2002). How to assess and interpret survey psychometrics. Sage Publications.

Lu, W.M. (2012). Intellectual capital and university performance in Taiwan. Economic Modelling, 29(4), 1081-1089. https://doi.org/10.1016/j.econmod.2012.03.021

Mariani, G., Carlesi, A., \& Scarfò, A.A. (2018). Academic spinoffs as a value driver for intellectual capital: The case of the University of Pisa. Journal of Intellectual Capital, 19(1), 202-226. https://doi.org/10.1108/JIC-03-2017-0050

Markus, K.A., \& Lin, C. (2010). Construct validity. In N. J. Salkind (Ed.), Encyclopedia of research design (pp. 229-233). Sage.

Markus, K.A., \& Smith, K.M. (2010). Content validity. In N. J. Salkind (Ed.), Encyclopedia of research design (pp. 238-243). Sage.

Martínez-Torres, M. R. (2006). A procedure to design a structural and measurement model of intellectual capital: An exploratory study. Information and Management, 43(5), 617-626. https://doi.org/10.1016/j.im.2006.03.002

Martinez, L.S. (2017). Validity, face and content. In M. Allen (Ed.), The SAGE encyclopedia of communication research methods (pp. 1822-1824). Sage Reference.

Martinková, P., \& Drabinová, A. (2018). ShinyItemAnalysis for teaching psychometrics and to enforce routine analysis of educational tests. The $R$ Journal, 10(2), 503-515. https://doi.org/10.32614/RJ-2018-074

Matos, F., Vairinhos, V., Selig, P. M., \& Edvinsson, L. (2019). Intellectual capital management as a driver of sustainability: Perspectives for organizations and society. Springer.

Mohamed, M. (2018). Challenges and benefits of industry 4.0: An overview. International Journal of Supply Operating Management, 5(3), 256-265. https://doi.org/10.22034/2018 .3 .7

Motta, G. (2017). Factor analysis. In M. Allen (Ed.), The SAGE encyclopedia of communication 
research methods (pp. 502-505). Sage Reference.

Mura, M., \& Longo, M. (2013). Developing a tool for intellectual capital assessment: An individual-level perspective. Expert Systems, 30(5), 436-450. https://doi.org/10.1111/j.1 468-0394.2012.00650.x

Nahapiet, J., \& Ghoshal, S. (1998). Social capital, intellectual capital, and the organizational change. Academy Ol Managemeni Review, 23(2), 242-266.

Netemeyer, R.G., Bearden, W.O., \& Sharma, S. (2003). Scaling procedures: Issues and applications. Sage Publications.

O’Connor, B.P. (2020). EFA.dimensions: Exploratory factor analysis functions for assessing dimensionality.

O'Donnell, D., \& O'Regan, P. (2000). The structural dimensions of intellectual capital: Emerging challenges for management and accounting. Southern African Business Review, 4(2), 14-20.

OECD/Eurostat. (2018). Oslo manual 2018: Guidelines for collecting, reporting and using data on innovation. OECD. https://doi.org/10.1787/9789264304604-en

Osburn, H.G. (2000). Coefficient alpha and related internal consistency reliability coefficients. Psychological Methods, 5(3), 343-355. https://doi.org/10.1037/1082-989X.5.3.343

Pedrini, M.P. (2007). Human capital convergences in intellectual capital and sustainability reports. Journal of Intellectual Capital, 8(2), 346-366. https://doi.org/10.1108/14691930 $\underline{710742880}$

Pedro, E. de M., Leitão, J., \& Alves, H. (2020). Bridging intellectual capital, sustainable development and quality of life in higher education institutions. Sustainability, 12(2), 127. https://doi.org/10.3390/su12020479

Preacher, K.J., Zhang, G., Kim, C., \& Mels, G. (2013). Choosing the optimal number of factors in exploratory factor analysis: A model selection perspective. Multivariate Behavioral Research, 48(1), 28-56. https://doi.org/10.1080/00273171.2012.710386

$\mathrm{R}$ Core Team. (2021). $R$ : A language and environment for statistical comouting. R Foundation for Statistical Computing. https://www.r-project.org/

Rae, G. (2007). A note on using stratified alpha to estimate the composite reliability of a test composed of interrelated nonhomogeneous items. Psychological Methods, 12(2), 177184. https://doi.org/10.1037/1082-989X.12.2.177

Ramírez, Y., \& Gordillo, S. (2013). Recognition of intellectual capital importance in the university sector. International Journal of Business and Social Research, 3(4), 27-41. https://doi.org/10.18533/ijbsr.v3i4.27

Ramírez, Y., \& Gordillo, S. (2014). Recognition and measurement of intellectual capital in Spanish universities. Journal of Intellectual Capital, 15(1), 173-188. https://doi.org/10.1 108/JIC-05-2013-0058

Ramírez Córcoles, Y., \& Tejada Ponce, Á. (2013). Cost-benefit analysis of intellectual capital disclosure: University stakeholders' view. Revista de Contabilidad-Spanish Accounting Review, 16(2), 106-117. https://doi.org/10.1016/j.rcsar.2013.07.001

Ramirez, Y., Tejada, A., \& Manzaneque, M. (2016). The value of disclosing intellectual capital in Spanish universities: A new challenge of our days. Journal of Organizational Change Management, 29(2), 176-198. https://doi.org/10.1108/JOCM-02-2015-0025

Ren, J.Y. (2009). The empirical study on the relationship between corporate intellectual capital and corporate performance. IE and EM 2009 - Proceedings 2009 IEEE 16th International Conference on Industrial Engineering and Engineering Management, 2054-2058. https://doi.org/10.1109/ICIEEM.2009.5344238

Revelle, W. (2020). psych: Procedures for personality and psychological research. Northwestern University.

Robitzsch, A. (2021). sirt: Supplementary item response theory models. R package version 


\subsection{1-21. https://cran.r-project.org/package $=$ sirt}

Roos, J., Roos, G., Edvinsson, L., \& Dragonetti, N. C. (1997). Intellectual capital: Navigating in the new business landscape. Macmillan Business.

Rosseel, Y. (2012). lavaan: An R package for structural equation modeling. Journal of Statistical Software, 48(2). http://dx.doi.org/10.18637/jss.v048.i02

Rstudio Team. (2021). RStudio: Integrated development for R. RStudio. https://www.rstudio.c om/

Saint-Ogne, H. (1996). Tacit knowledge the key to the strategic alignment of intellectual capital. Planning Review, 24(2), 10-16. https://doi.org/10.1108/eb054547

Sánchez, M.P., Elena, S., \& Castrillo, R. (2009). Intellectual capital dynamics in universities: A reporting model. Journal of Intellectual Capital, 10(2), 307-324. https://doi.org/10.1108/14691930910952687

Schermelleh-Engel, K., Moosbrugger, H., \& Müller, H. (2003). Evaluating the fit of structural equation models: Tests of significance and descriptive goodness-of-fit measures. Methods of Psychological Research Online, 8, 23-74.

Schmitt, T.A. (2011). Current methodological considerations in exploratory and confirmatory factor analysis. Journal of Psychoeducational Assessment, 29(4), 304-321. https://doi.org/10.1177/0734282911406653

Schneider, P. (2018). Managerial challenges of Industry 4.0: an empirically backed research agenda for a nascent field. Review of Managerial Science, 12(3), 803-848. https://doi.org/10.1007/s11846-018-0283-2

Schumacker, R.E., \& Lomax, R.G. (2016). A beginner's guide to structural equation modeling. Routledge.

Segars, A.H., \& Grover, V. (1993). Re-examining perceived ease of use and usefulness: A confirmatory factor analysis. MIS Quarterly: Management Information Systems, 17(4), 517-525. https://doi.org/10.2307/249590

Semenov, V. (2016). Institutional features of strategic management of intellectual capital reproduction. 2015 4th Forum Strategic Partnership of Universities and Enterprises of Hi-Tech Branches (Science. Education. Innovation), 52-54. https://doi.org/10.1109/IVF orum.2015.7388251

Silva, T.M., \& Ferreira, A. (2019). Intellectual capital sustainability in Brazilian public higher education. In F. Matos, V. Vairinhos, P. M. Selig, \& L. Edvinsson (Eds.), Intellectual capital management as a driver of sustainability: Perspectives for organizations and society. Springer.

Sohrabi, B., Raeesi, I., \& Khanlari, A. (2010). Intellectual capital components, measurement and management: A literature survey of concepts and measures. In P. L. Sáez, G. M. de Castro, J. E. N. López, \& M. Delgado-Verde (Eds.), Intellectual capital and technological innovation: Knowledge-based theory and practice (pp. 1-38). Information Science Reference.

Steiger, J.H. (2007). Understanding the limitations of global fit assessment in structural equation modeling. Personality and Individual Differences, 42(5), 893-898. https://doi.org/10.1016/j.paid.2006.09.017

Steiner, M.D., \& Grieder, S.G. (2020). EFAtools: An R package with fast and flexible implementations of exploratory factor analysis tools. Journal of Open Source Software, 5(53). https://doi.org/10.21105/joss.02521

Subramaniam, M., \& Youndt, M.A. (2005). The influence of intellectual capital on the types of innovative capabilities. Academy of Management Journal, 48(3), 450-463. https://doi.org/10.5465/amj.2005.17407911

Suciu, M., \& Năsulea, D. (2019). Intellectual capital and creative economy as key drivers for competitiveness towards a smart and sustainable development: Challenges and 
opportunities for cultural and creative communities. In F. Matos, V. Vairinhos, P. M. Selig, \& L. Edvinsson (Eds.), Intellectual capital management as a driver of sustainability: Perspectives for organizations and society (pp. 67-97). Springer.

Sultan, P., \& Wong, H.Y. (2019). How service quality affects university brand performance, university brand image and behavioural intention: the mediating effects of satisfaction and trust and moderating roles of gender and study mode. Journal of Brand Management, 26(3), 332-347. https://doi.org/10.1057/s41262-018-0131-3

Şencan, H. (2005). Sosyal ve davranışsal ölçümlerde güvenilirlik ve geçerlilik [Reliability and validity in social and behavioral measures]. Seçkin.

Tabachnick, B.G., \& Fidell, L.S. (2014). Using multivariate statistics. Pearson.

Tajvidi, M., \& Karami, A. (2015). Product development strategy: Innovation capacity and entrepreneurial firm performance in high-tech SMEs. Palgrave Macmillan.

Todericiu, R., \& Stanit, A. (2016). Universities intellectual capital. Management and Economics, 4(84), 348-356.

Todericiu, R., \& Şerban, A. (2015). Intellectual capital and its relationship with universities. Procedia Economics and Finance, 27(15), 713-717. https://doi.org/10.1016/s2212$\underline{5671(15) 01052-7}$

Ullman, J.B. (2014). Structural equation modeling. In B. G. Tabachnick \& L. S. Fidell (Eds.), Using multivariate statistics (pp. 731-836). Pearson.

Urban, B., \& Joubert, G.C.D.S. (2017). Multidimensional and comparative study on intellectual capital and organisational performance. Journal of Business Economics and Management, 18(1), 84-99. https://doi.org/10.3846/16111699.2016.1255990

Watkins, M.W. (2021). A step-by-step guide to exploratory factor analysis with R and RStudio. In A Step-by-Step Guide to Exploratory Factor Analysis with $R$ and RStudio. Routledge. https://doi.org/10.4324/9781003120001

Welch, G.W. (2010). Confirmatory factor analysis. In N. J. Salkind (Ed.), Encyclopedia of research design (pp. 216-220). Sage.

Wickham, H., François, R., Henry, L., \& Müller, K. (2020). dplyr: A grammar of data manipulation.

Williams, B., Onsman, A., \& Brown, T. (2010). Exploratory factor analysis: A five-step guide for novices. Journal of Emergency Primary Health Care (JEPHC), 8(3), 1-13. https://doi.org/10.33151/ajp.8.3.93

Wilson, F.R., Pan, W., \& Schumsky, D.A. (2012). Recalculation of the critical values for Lawshe's content validity ratio. Measurement and Evaluation in Counseling and Development, 45(3), 197-210. https://doi.org/10.1177/0748175612440286

Worthington, R.L., \& Whittaker, T.A. (2006). Scale development research: A content analysis and recommendations for best practices. The Counseling Psychologist, 34(6), 806-838. https://doi.org/10.1177/0011000006288127

Youndt, M. A., \& Snell, S. A. (2004). Human resource configurations, intellectual capital, and organizational performance. Journal of Managerial Issues, 16(3), 337-360. 


\section{APPENDIX}

Table A1. Turkish version of Academic Intellectual Capital Scale.

\begin{tabular}{|c|c|c|c|c|c|c|}
\hline 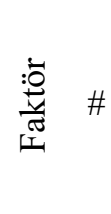 & Madde & 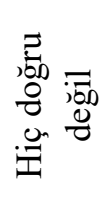 & 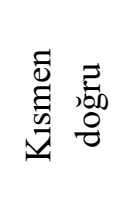 & 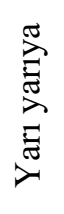 & 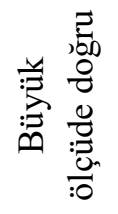 & 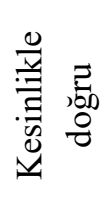 \\
\hline \multirow{6}{*}{ 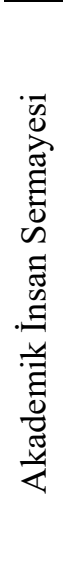 } & $\begin{array}{l}\text { Üniversitemizde bilimsel araştırmaya odaklanmış güçlü bir } \\
\text { akademik kültür vardır. }\end{array}$ & 1 & 2 & 3 & 4 & 5 \\
\hline & $\begin{array}{l}\text { Üniversitemizdeki öğretim elemanları, öğrencileri girişimciliğe } \\
\text { teşvik eder. }\end{array}$ & 1 & 2 & 3 & 4 & 5 \\
\hline & $\begin{array}{l}\text { Üniversitemizdeki öğretim elemanları, yüksek akademik } \\
\text { niteliklere sahiptir. }\end{array}$ & 1 & 2 & 3 & 4 & 5 \\
\hline & $\begin{array}{l}\text { Üniversitemiz, alanlarının en başarılı öğretim elemanlarına } \\
\text { sahiptir. }\end{array}$ & 1 & 2 & 3 & 4 & 5 \\
\hline & $\begin{array}{l}\text { Üniversitemiz, özgün fikirleriyle bilinen öğretim elemanlarına } \\
\text { sahiptir. }\end{array}$ & 1 & 2 & 3 & 4 & 5 \\
\hline & $\begin{array}{l}\text { Üniversitemizdeki öğretim elemanları, öğrencileri ekip çalışması } \\
\text { yapmaya teşvik eder. }\end{array}$ & 1 & 2 & 3 & 4 & 5 \\
\hline \multirow{6}{*}{ 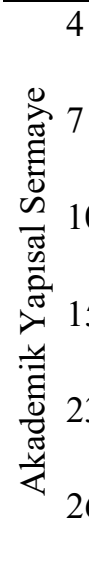 } & $\begin{array}{l}\text { Üniversitemiz, verilen eğitim içeriğini destekleyecek nitelikte } \\
\text { dijital donanıma sahiptir. }\end{array}$ & 1 & 2 & 3 & 4 & 5 \\
\hline & $\begin{array}{l}\text { Üniversitemiz, verilen eğitim içeriğini destekleyecek nitelikte } \\
\text { bina, donatı, vb. fiziki olanaklara sahiptir. }\end{array}$ & 1 & 2 & 3 & 4 & 5 \\
\hline & $\begin{array}{l}\text { Üniversitemizde ihtiyaçlara cevap verecek nitelikte bir bilgi } \\
\text { yönetim sistemi (ders seçimi, not takibi vb.) kullanılır. }\end{array}$ & 1 & 2 & 3 & 4 & 5 \\
\hline & $\begin{array}{l}\text { Üniversitemiz, ihtiyaca cevap verecek nitelikte bir e-öğrenme } \\
\text { platformuna sahiptir. }\end{array}$ & 1 & 2 & 3 & 4 & 5 \\
\hline & $\begin{array}{l}\text { Üniversitemizdeki bilgi yönetim sistemi (ders seçimi, not takibi } \\
\text { vb.), öğretim elemanları tarafından etkin bir şekilde kullanılır. }\end{array}$ & 1 & 2 & 3 & 4 & 5 \\
\hline & $\begin{array}{l}\text { Üniversitemizdeki bilgi yönetim sistemi (ders seçimi, not takibi } \\
\text { vb.), öğrenciler tarafından etkin bir şekilde kullanılır. }\end{array}$ & 1 & 2 & 3 & 4 & 5 \\
\hline \multirow{8}{*}{ 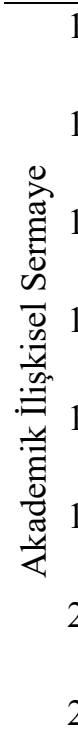 } & $\begin{array}{l}\text { Üniversitemizde karar verilirken mezun öğrencilerin fikirleri } \\
\text { dikkate alınır. }\end{array}$ & 1 & 2 & 3 & 4 & 5 \\
\hline & $\begin{array}{l}\text { Üniversitemizin, iş dünyasında faaliyet gösteren kurumlarla iş } \\
\text { birliği protokolleri vardır. }\end{array}$ & 1 & 2 & 3 & 4 & 5 \\
\hline & $\begin{array}{l}\text { Üniversitemizin, sektördeki kuruluşlarla imzalanmış mezun işe } \\
\text { alım protokolleri vardır. }\end{array}$ & 1 & 2 & 3 & 4 & 5 \\
\hline & $\begin{array}{l}\text { Üniversitemizin başka üniversitelerle iş birliği protokolleri } \\
\text { vardır. }\end{array}$ & 1 & 2 & 3 & 4 & 5 \\
\hline & $\begin{array}{l}\text { Üniversitemiz bünyesinde işlevsel bir teknoloji transfer birimi } \\
\text { vardır. }\end{array}$ & 1 & 2 & 3 & 4 & 5 \\
\hline & $\begin{array}{l}\text { Üniversitemizde, bilimsel anlayışı topluma yaymaya yönelik } \\
\text { etkinlikler düzenlenir. }\end{array}$ & 1 & 2 & 3 & 4 & 5 \\
\hline & $\begin{array}{l}\text { Üniversitemizde çevre sorumluluğuna ilişkin etkinlikler } \\
\text { düzenlenir. }\end{array}$ & 1 & 2 & 3 & 4 & 5 \\
\hline & Üniversitemiz, yeni iş girişimi (start-up) firmalarını destekler. & 1 & 2 & 3 & 4 & 5 \\
\hline
\end{tabular}

